\title{
Trends and inequities in use of maternal health care services in Indonesia, | 986-2012
}

This article was published in the following Dove Press journal: International Journal of Women's Health

\author{
Herfina Y Nababan' \\ Md Hasan ${ }^{2}$ \\ Tiara Marthias ${ }^{1,3}$ \\ Rolina Dhital ${ }^{4}$ \\ Aminur Rahman² \\ Iqbal Anwar ${ }^{2}$
}

'Nossal Institute for Global Health, Melbourne School of Population and Global Health, the University of Melbourne, Parkville, Melbourne, VIC, Australia; ${ }^{2} \mathrm{Health}$ Systems and Population Studies Division, icddr,b, Mohakhali, Dhaka, Bangladesh; ${ }^{3}$ Center for Health Policy and Management, Faculty of Medicine, Universitas Gadjah Mada, Yogyakarta, Indonesia; ${ }^{4}$ FIGO Post-Partum IUD Initiative Nepal, Nepal Society of Obstetrician and Gynaecologists (NESOG), Kathmandu, Nepal
Correspondence: Iqbal Anwar Health Systems and Population Studies Division, icddr,b, 68 Shaheed Tajuddin Ahmed Sarani, Mohakhali, Dhaka 1212, Bangladesh

Tel +8801732292737

Email iqbal@icddrb.org
Purpose: Overall health status indicators have improved significantly over the past three decades in Indonesia. However, the country's maternal mortality ratio remains high with a stark inequality by region. Fewer studies have explored access inequity in maternal health care service over time using multiple inequality markers. In this study, we analyzed Indonesian Demographic and Health Survey (DHS) data to explore trends and inequities in use of any antenatal care (ANC), four or more ANC (ANC4+), institutional birth, and cesarean section (c-section) birth in Indonesia during 1986-2012 to inform policy for future strategies ending preventable maternal deaths.

Methods: Indonesian DHS data from 1991, 1994, 1997, 2002/3, 2007, and 2012 surveys were downloaded, merged, and analyzed. Inequity was measured in terms of variation in use by asset quintile, parental education, urban-rural location, religion, and region. Trends in use inequities were assessed plotting changes in rich:poor ratio, rich:poor difference, and concentration indices over period based on asset quintiles. Sociodemographic determinants for service use were explored using multivariable logistic regression analysis.

Findings: Between 1986 and 2012, institutional birth rate increased from $22 \%$ to $73 \%$ and c-section rate from $2 \%$ to $16 \%$. Private sector was increasingly contributing in maternal health. There were significant access inequities by asset quintile, parental education, area of residence, and geographical region. The richest women were 5.45 times (95\% CI: 4.75-6.25) more likely to give birth in a health facility and 2.83 times (95\% CI: $2.23-3.60)$ more likely to give birth by c-section than their poorest counterparts. Urban women were 3 times more likely to use institutional birth and 1.45 times more likely to give birth by c-section than rural women. Use of all services was higher in Java and Bali than in other regions. Access inequity was narrowing over time for use of ANC and institutional birth but not for c-section birth.

Conclusion: Ongoing pro-poor health-financing strategies should be strengthened with introduction of innovative ways to monitor access, equity, and quality of care in maternal health.

Keywords: health inequity, health inequality, maternal health, health service utilization, universal health coverage, sustainable development goal

\section{Introduction}

Strategies for reduction of maternal mortality ratio (MMR) have undergone many changes since inception of the Safe Motherhood Initiative in $1987 .{ }^{1}$ The current global recommendation is for all births to be guided by a skilled birth attendant supported by effective referral linkage with hospitals capable of performing blood transfusion and surgery. ${ }^{2}$ Inequity has been identified as a key constraint in maternal health as existing data depict huge inequity between and within countries with regard to both access to care and levels of MMR. ${ }^{3}$ Several innovative demand side health financing models have been initiated in different contexts. ${ }^{4}$ However, their evaluations remain insufficient. In addition, monitoring of progress in Millennium Development 
Goals (MDGs) paid inadequate attention to equity..$^{5}$ The drive toward universal health coverage (UHC) is central to the post-2015 Sustainable Development Goals (SDGs) that prioritizes health equity with specific call to reduce inequality - referring to any quantifiable differences, variations, and disparities in different aspects of health across individuals or social groups, ${ }^{6}$ as well as within and between countries. $^{7}$ Accordingly, a global framework has been developed to disaggregate SDG targets and indicators by sociodemographic strata in order to allow the assessment of equitable service distribution. ${ }^{8}$

Indonesia is home to around 13,000 islands with hundreds of diverse ethnic groups, ${ }^{9}$ grouped into 34 provinces, 98 municipalities, and 410 districts. ${ }^{10}$ Some regions are more developed in terms of economy, education, and infrastructure. ${ }^{9}$ The wealthiest, the urban, and those living in Java and Bali enjoy better availability and access to basic services including health. ${ }^{11,12}$ Health status indicators have improved, with life expectancy rising from 63 years in 1990 to 71 years in 2012, under-five mortality falling from 52 to 31 deaths per 1,000 live births and infant mortality falling from 41 to 26 deaths per 1,000 live-births between 2000 and 2012. ${ }^{13}$ However, MMR remained high (210 deaths per 100,000 live births in 2010), and a stark inequality persists across regions. For example, in Papua - the most Eastern part of Indonesia - the MMR was 573 per 100,000 live births in 2010, more than double of the national estimate during that period. ${ }^{14}$ The high MMR with prevailing inequity fundamentally violates Indonesian women's right to health. ${ }^{15}$

The government is striving for the highest possible standard of health for all women in the country. ${ }^{16}$ A number of evolving maternal health and health-financing strategies have been implemented. Important among them are the village midwife program, ${ }^{17}$ the insurance program for maternal and child health, ${ }^{18}$ and the placement and incentive programs in underserved areas. ${ }^{11,19,20}$ A National Health Insurance Program (Jaminan Kesehatans Nasional[JKN]) have been launched in 2014 to facilitate achieving UHC. ${ }^{21}$ Country data suggest some improvement in terms of service coverage, but not equity. ${ }^{22}$ Fewer studies in Indonesia have explored access inequity in maternal health over time using multiple inequality markers. Demographic and Health Surveys (DHS) provide unique opportunity for tracking health inequities over time and between countries. In this paper, we analyzed six consecutive Indonesian Demographic and Health Survey (IDHS) data to explore trends and inequities in access to key maternal health care services between 1986 and 2012 to inform policy for future strategies ending preventable maternal deaths.

\section{Methods}

With permission from MEASURE DHS (www.measuredhs. com), we downloaded, merged, and analyzed the 1991, 1994, 1997, 2002/3, 2007, and 2012 Indonesian DHS datasets to explore trends, inequities, and determinants of maternal health care service utilization in Indonesia. This study was exempt from review by the ethics committee because the data used were publicly available and no respondent information was obtained. Before receiving access to the data, an electronic registration form highlighting the desired data and plan for analysis was submitted and approved by MEASURE DHS. All data were reported in aggregate, and no attempt was made to identify study participants.

The current study explored service utilization among women in Indonesia who gave their last birth in the 3 years prior to each survey year. The outcome measures focused on the utilization of any antenatal care (any ANC), four or more ANC (ANC4+), institutional birth, and birth by cesarean section (c-section). The inclusion of any ANC and ANC4+ was based on World Health Organization (WHO) recommendation that ANC is fundamental to ensure the delivery of effective and appropriate screening, prevention, and treatment of complication around pregnancy. ${ }^{23}$ The recommendation suggests a minimum of four focused ANCs as a lower number of visits has been associated with increased likelihood of perinatal morbidity. ${ }^{23}$ Inequities were measured in terms of inequality in access by different sociodemographic characteristics including asset quintiles, parental education (none, primary, secondary, or higher), clusters of regions (Sumatera, Java and Bali, Nusa Tenggara, Kalimantan, Sulawesi, or Maluku and Papua), areas of residence (urban or rural), and religions (Islam or others). Influence of maternal age (categorized into five age groups), birth order (1, 2, 3, 4, 5, or $6+$ ), and year of birth upon use of maternal health care services was also explored. ${ }^{11}$

Asset quintiles were computed survey year-wise following principal component and factor analysis methods using information on construction material of floor, wall, and roof; the source of drinking water; the type of latrine; electricity supply; and ownership of radio, telephone, motorcycle, television, car, and bicycle. ${ }^{24}$ The trends and inequities were examined at 4-year time intervals (except for the year 20102012, which covered 3 years). Sociodemographic determinants were explored using multivariable logistic regression analysis, by quantifying both unadjusted and adjusted odds ratios (ORs) for each of the outcome variables using Wald tests to assess statistical significance (with 95\% CIs and level of significance $<0.05$ ), taking into account survey design (sampling weights and strata) and clustering effect. 
To look into trends in inequities, we used relative measurement of rich:poor ratio; absolute measurement of rich:poor difference; and the concentration index (with 95\% CIs). The concentration index is considered as a better measurement of inequality, which quantifies how specific goods and services are distributed among different socioeconomic groups. The value of the index varies between +1 and -1 ; positive values indicate a higher concentration of services among higher socioeconomic groups and vice versa. If there is no socioeconomic-related inequity, the concentration index would be zero. ${ }^{25}$ Unadjusted and adjusted annual time trends for each of the outcome variables were also explored to determine whether the odds of use of maternal health care services were improving at the same rate in different socioeconomic groups. All statistical analyses were performed in Stata 14 (StataCorp, College Station, TX, USA). ${ }^{26}$

\section{Result \\ Trends in sociodemographic characteristics of women}

In this study, we included 104,220 women in the final analysis who gave birth between 1986 and 2012. Table 1 shows

Table I Trends in sociodemographic characteristics in Indonesia (I986-2012)

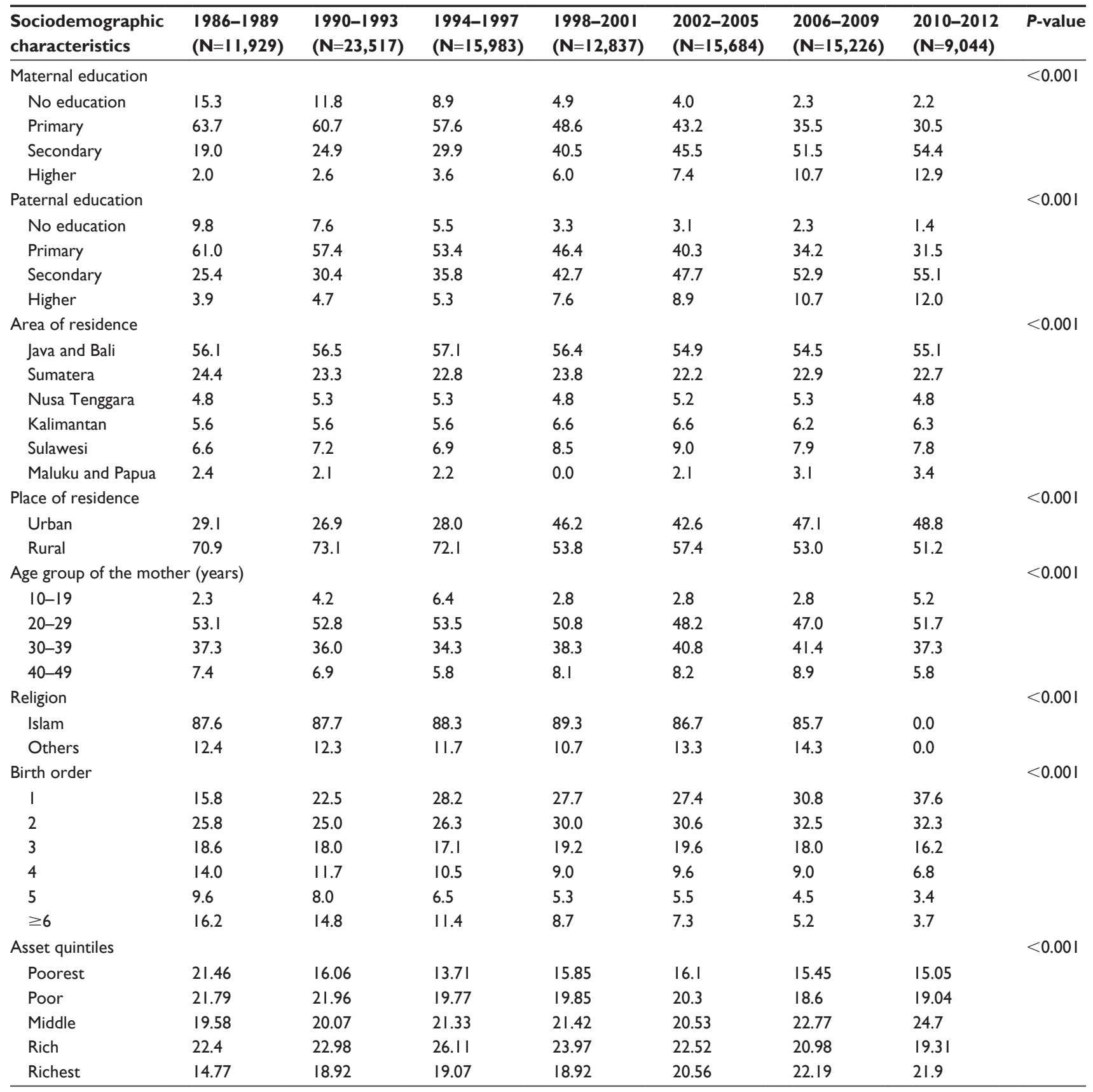


considerable changes in sociodemographic characteristics of women over the past 25 years. The percentage of women with no education decreased from $15.3 \%$ in 1986-1989 to $2.2 \%$ in 2010-2012, while the percentage of husbands with no education reduced from $9.8 \%$ to $1.4 \%$ during the same period. The percentage of urban population increased from $29.1 \%$ in $1986-1989$ to $48.8 \%$ in $2010-2012$. During the study period, the percentage of households from the lowest asset quintile group dropped from $21.46 \%$ to $15.05 \%$ and those from the highest asset quintile group grew from $14.77 \%$ to $21.9 \%$. There was a significant demographic shift as well; the proportion of adolescent mothers increased from $2.26 \%$ to $5.22 \%$; the primigravidae mothers increased from $15.8 \%$ to $37.6 \%$; and women with 6 or more birth order reduced from $16.2 \%$ to $3.72 \%$ between 1986 and 2012 (Table 1 ).

\section{Trends in maternal health care service utilization}

Figure 1 shows that between 1986 and 2012, the utilization of any ANC increased from $81 \%$ to $95 \%$, the use of ANC4+ increased from $61 \%$ to $85 \%$, institutional birth increased from $22 \%$ to $73 \%$, and c-section birth increased from $2 \%$ to $16 \%$. A sharp increase in institutional birth was observed after 1998. Population-based c-section rate increased steadily and just crossed the upper limit of global recommendation of $15 \%$ in 2012 .

Table 2 presents the annual trends of use showing that during the study period, the utilization of any ANC services was actually decreasing at a rate of $5 \%$ per year, and the use of ANC4+ remained the same, while an increasing trend was observed for uptake of both institutional birth (5\% per year) and c-section birth (4\% per year). Annual trend for institutional birth was better among the poorer and rural women and in Nusa Tenggara region. For c-section birth, the trend was higher among wealthier households, in urban areas, and in Nusa Tenggara region. Annual trend for institutional birth was 7\% among rural women and 3\% among urban women. However, the annual trend for c-section favored the urban women $(4 \%)$ than rural $(3 \%)$ and the richest women $(5 \%)$ than the poorest $(3 \%)$.

\section{Place of birth}

Figure 1 shows that institutional birth rate increased from $22 \%$ to $73 \%$ between 1986 and 2012; however, the increase was contributed mainly by the private sector facilities (Figure 2). Institutional birth in private facilities increased from $11.2 \%$ to $48.1 \%$, while in public sector facilities the increase was only $\sim 10 \%$ from $9.1 \%$ to $19.6 \%$. There was no increase in home birth by skilled birth attendants since 1998 .

\section{Sociodemographic determinants of maternal health care service utilization}

Multivariable logistic regression analysis showed statistically significant relationship between sociodemographic factors and use variables included in the analysis (Table 3). In the model where effects of covariates were controlled statistically, all sociodemographic variables evolved as significant predictors for use of any ANC, ANC4+, institutional birth, and birth by c-section. However, the strength

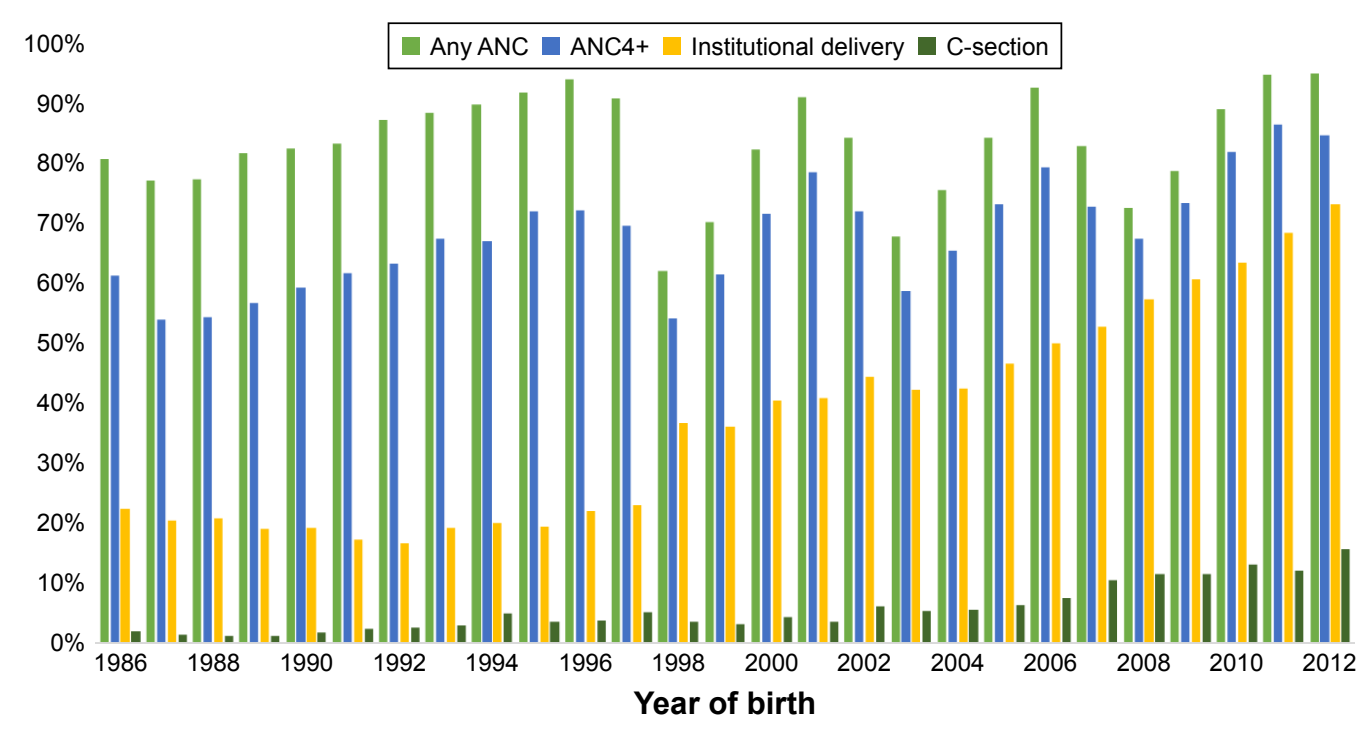

Figure I Trend in the use of any ANC, ANC4+, institutional delivery, and c-section (1986-20I2). Abbreviation: ANC, antenatal care. 


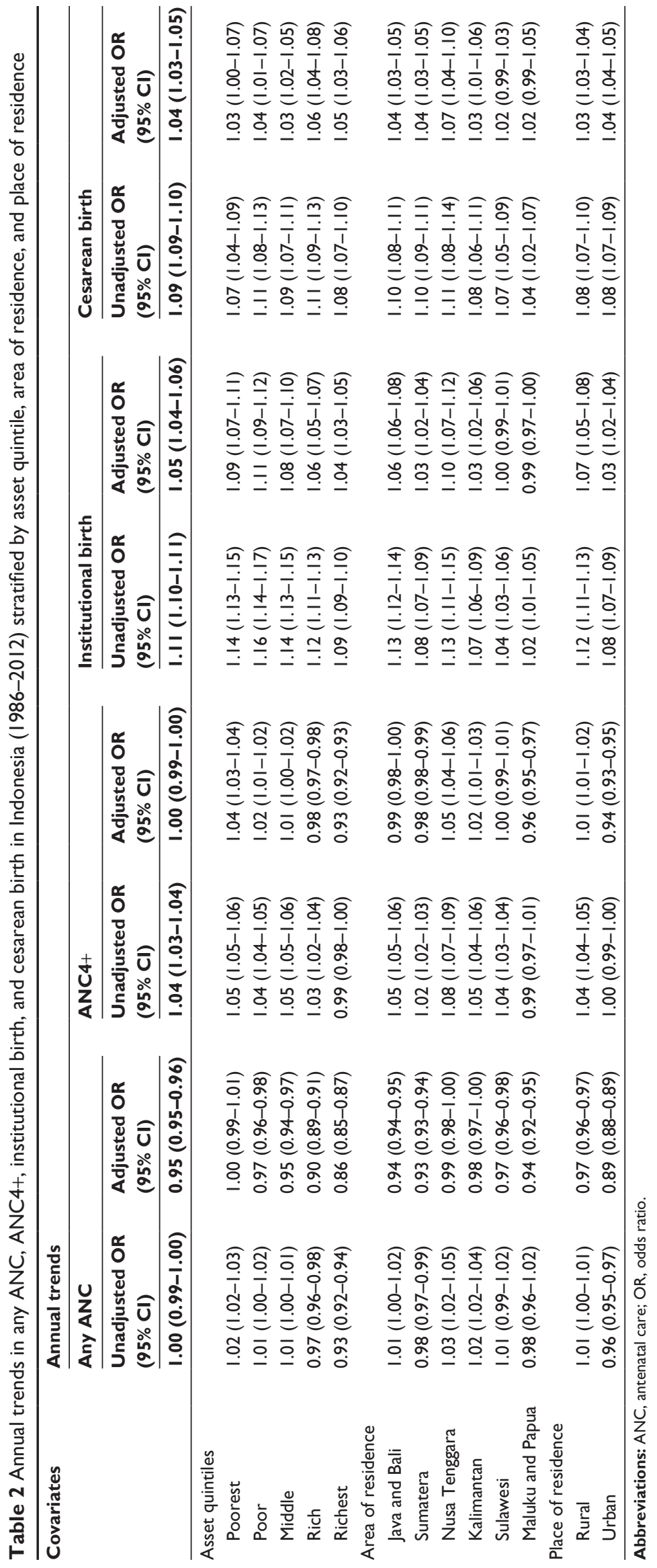




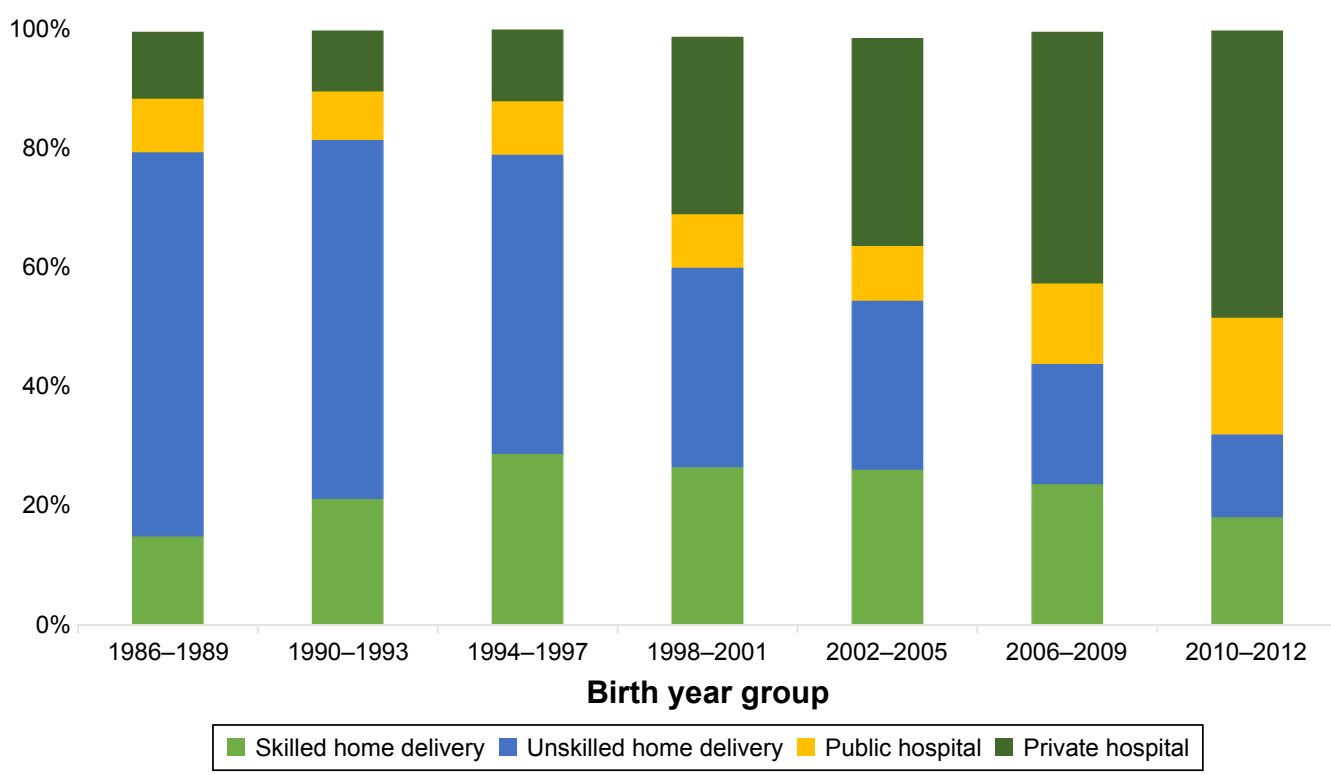

Figure 2 Trends in distribution of place of delivery.

and direction of associations varied. There was significant use inequity by asset quintile, education, area of residence, and region. A mother from the richest quintile household was 5.45 times (adjusted OR: 5.45; 95\% CI: 4.75-6.25) more likely to give birth in a health facility than a mother from the poorest quintile household. Similarly, the richest quintile mothers were 2.83 times (adjusted OR: 2.83; 95\% CI: $2.23-3.60$ ) more likely to give birth by c-section than their poorest counterpart. Education of mothers evolved as the number one predictor for use of c-section birth and for institutional birth. A mother with higher education was 4.36 times (adjusted OR: 4.36; 95\% CI: 3.46-5.50) more likely to give birth at health facility and 3.12 times (adjusted OR: 3.12 ; 95\% CI: $1.89-5.15)$ more likely to give birth by c-section than her illiterate counterpart. Utilization also varied significantly by religion, area of residence, and region. Uses were higher among non-Muslims, in urban area and in Java and Bali Sumatera region. By geographic location and using Java and Bali as the reference, there was lower propensity of women from other regions to use maternal health care services. Women from Maluku and Papua used the services the least, and they were about $50 \%$ less likely to use any ANC (adjusted OR: 0.45; 95\% CI: 0.36-0.55), ANC4+ (adjusted OR: 0.53; 95\% CI: 0.47-0.59), and institutional birth (adjusted OR: 0.45 ; 95\% CI: 0.39-0.52), and about $20 \%$ less likely to give birth by c-section (adjusted OR: 0.76 ; 95\% CI: 0.61-0.94) than women from Java and Bali. Older age and lower parity were positively correlated with service utilization (Table 3).

\section{Trends in inequities in maternal health care service utilization}

In Figures 3-6, we have plotted rich:poor ratio, rich-poor difference, and concentration indices based on asset quintiles to show changes in equity in maternal health care services utilization. Findings show signs of improvement in addressing access inequity in use of any ANC, ANC4+, and institutional births. For institutional birth, rich:poor ratio reduced from 20.3 to 2.6, while concentration index reduced from 0.53 to 0.15 between 1986-1989 and 2010-2012 (Figure 5). However, no sign of equity gain was observed for c-section (Figure 6).

\section{Discussion}

The current study revealed that Indonesia is experiencing a positive change in the social determinants of health over the past two to three decades. There has been a shift in demographic characteristics of women, from high to low parity and from older to younger age-group mothers. However, an increase in the proportion of adolescent mothers is worrying. Overall, utilization of maternal health care services has increased, reflecting improved coverage and access. There was variation in utilization across urban-rural and geographical regions. Women who lived in Java-Bali and in urban areas used maternal health care services more. Use inequity persisted for all use variables, and by all inequality measures. Nevertheless, access inequity in terms of asset quintile was reducing over time, and for all use variables except for c-section birth. Private sector was increasingly contributing 


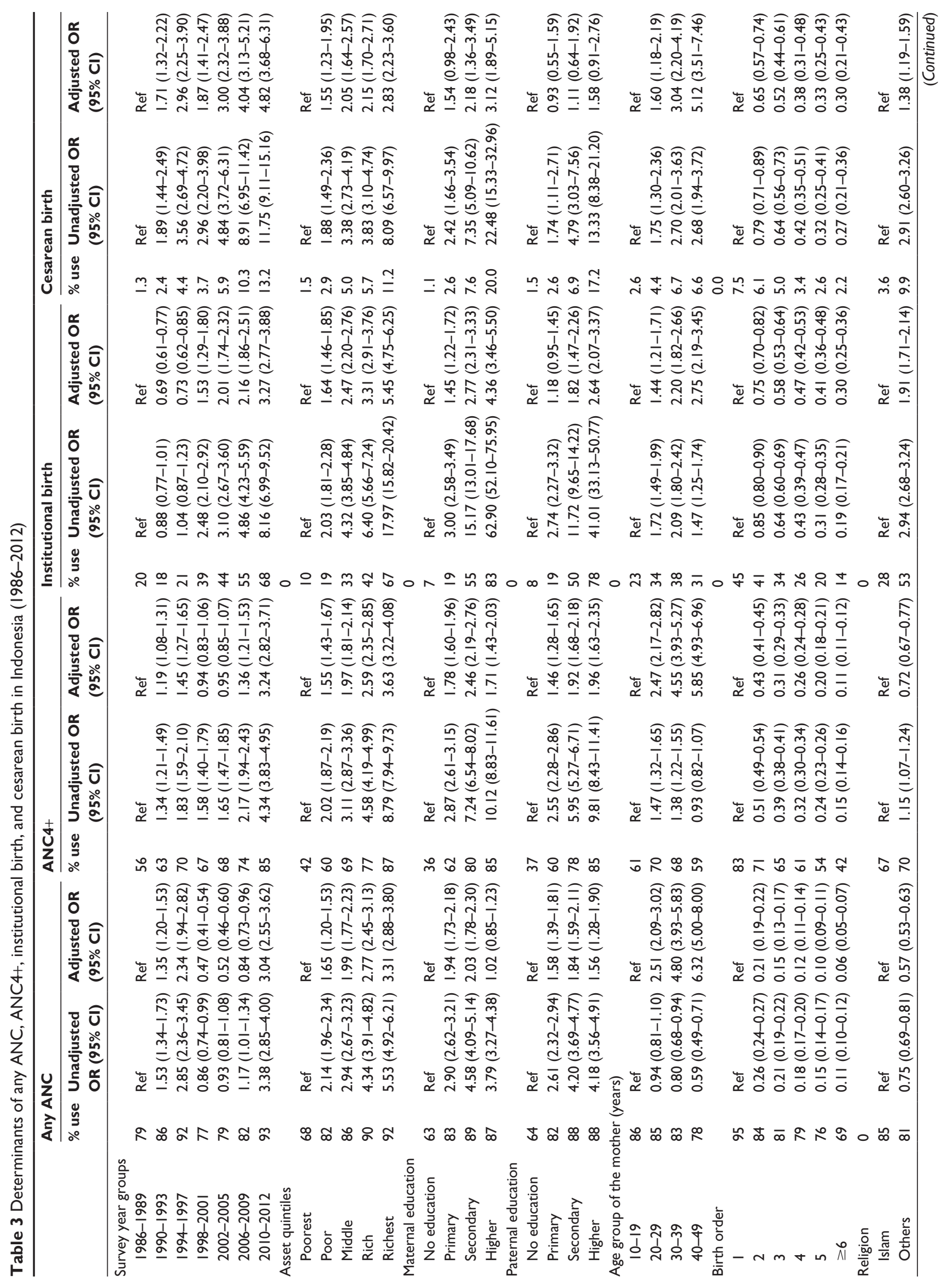




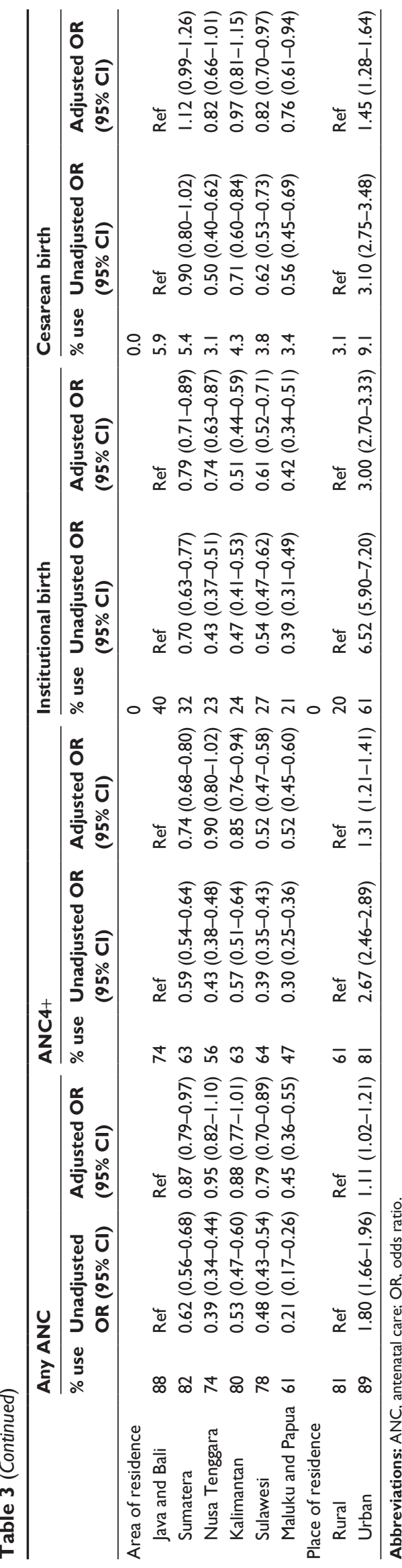

in maternal health as caregivers. Further reduction in use inequity remains imperative to decrease maternal mortality and to achieve SDG target for maternal health. ${ }^{27}$

Indonesia is a vast and diverse country geographically and culturally. ${ }^{9}$ Some regions in Indonesia, especially Java-Bali, are more developed than the others in terms of economic activity, infrastructure, and population, ${ }^{9}$ which has created differences in availability and access to basic services such as education and health. ${ }^{11}$ Inequity between regions, richpoor, and urban-rural characterize the health care situation in Indonesia. ${ }^{28}$ The capital city Jakarta and several big cities in Java and Bali have higher density of health facilities and health workers. ${ }^{28}$ Moreover, the richest and living in urban settings have bigger propensity to access health facilities than their poorest counterparts. ${ }^{12}$ Nonetheless, economic growth has been attributed as the driving force behind the positive change in social determinants of health in Indonesia, ${ }^{29,30}$ resulting in education attainment gain, urbanization, and improved household possessions as observed in this study. These improvements are promising with the given established influence upon women's status and health. ${ }^{15,31,32}$ Maternal education evolved as number one predictor of use of institutional and c-section birth in our study. Literature suggests that female education improves health awareness leading to the ability of seeking appropriate care. ${ }^{31-33}$

Our study confirmed that substantial use inequity persists in maternal health in Indonesia; however, it varied between outcome indicators, it had been narrowed for use of any ANC, ANC4+, and institutional birth, but remained high for c-section birth. Our analysis depicts that although overall use of c-section was increasing, use inequity was deteriorating. This costly surgical procedure was increasingly favoring the richer, educated, and urban women, indicating that the most vulnerable groups of women who actually need these lifesaving services may still fail to access them. The c-section rate among women from the poorest quintile households for instance was less than global recommendations of minimum 5\% during 2010-2012. Such inequity probably partially explains the failure of Indonesia in attaining MDG 5 goal in reducing MMR by three-quarters ${ }^{34}$ and possibly had a negative impact on MDG 4 target as well as in reducing under-five mortality rate by two-thirds of the baseline in $1990 .{ }^{35}$

Along with education and economic status, geographic location is of equal importance. ${ }^{15,36-38}$ In this study, utilization was significantly lower in rural areas and outside of Java-Bali regions. Our results corroborate with finding from previous studies as similar disparities in terms of rural-urban and regional differential in health outcomes have been reported 


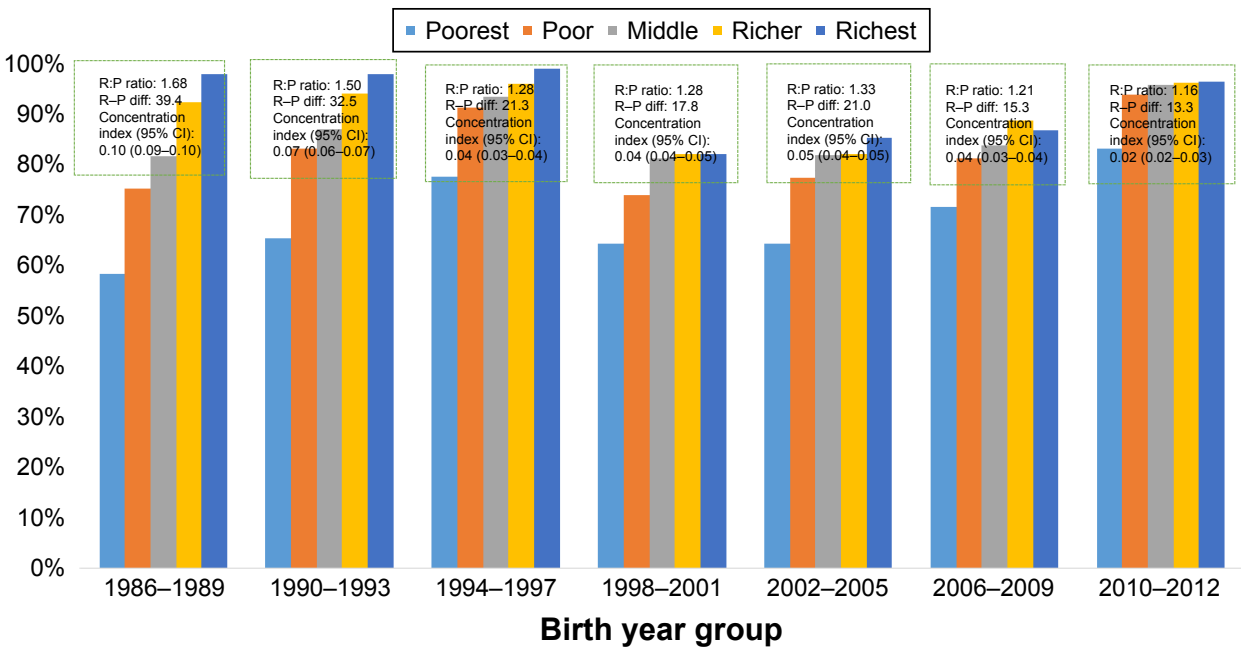

Figure 3 Trend in use inequity for any ANC.

Abbreviation: ANC, antenatal care.

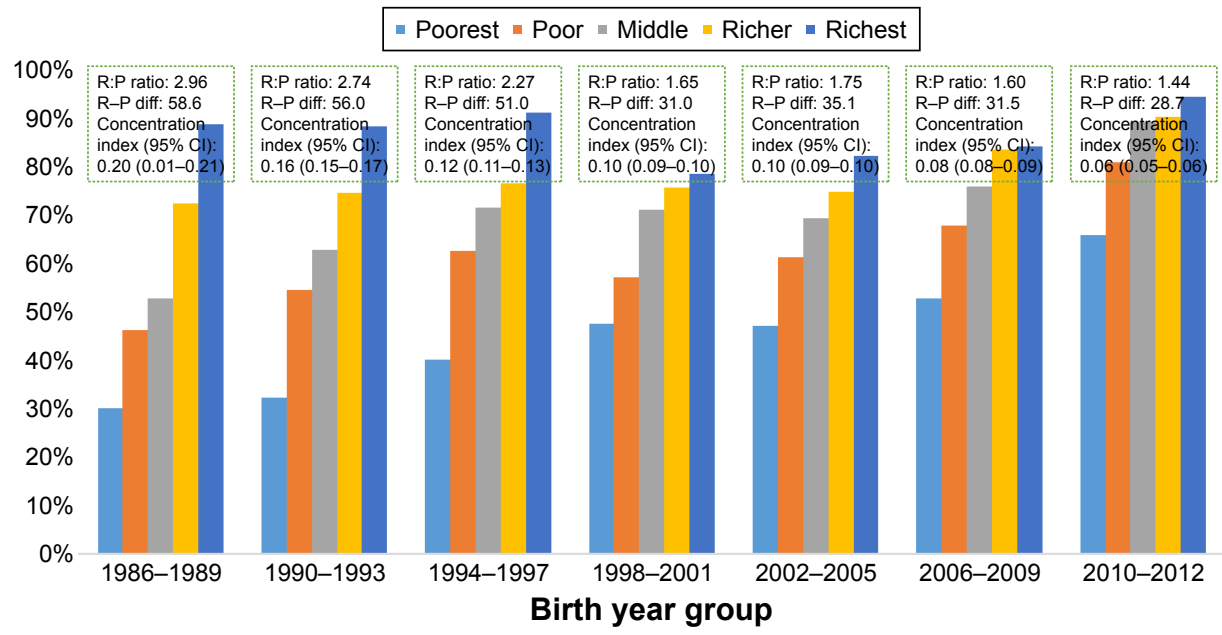

Figure 4 Trend in use inequity for ANC4+.

Abbreviation: ANC, antenatal care.

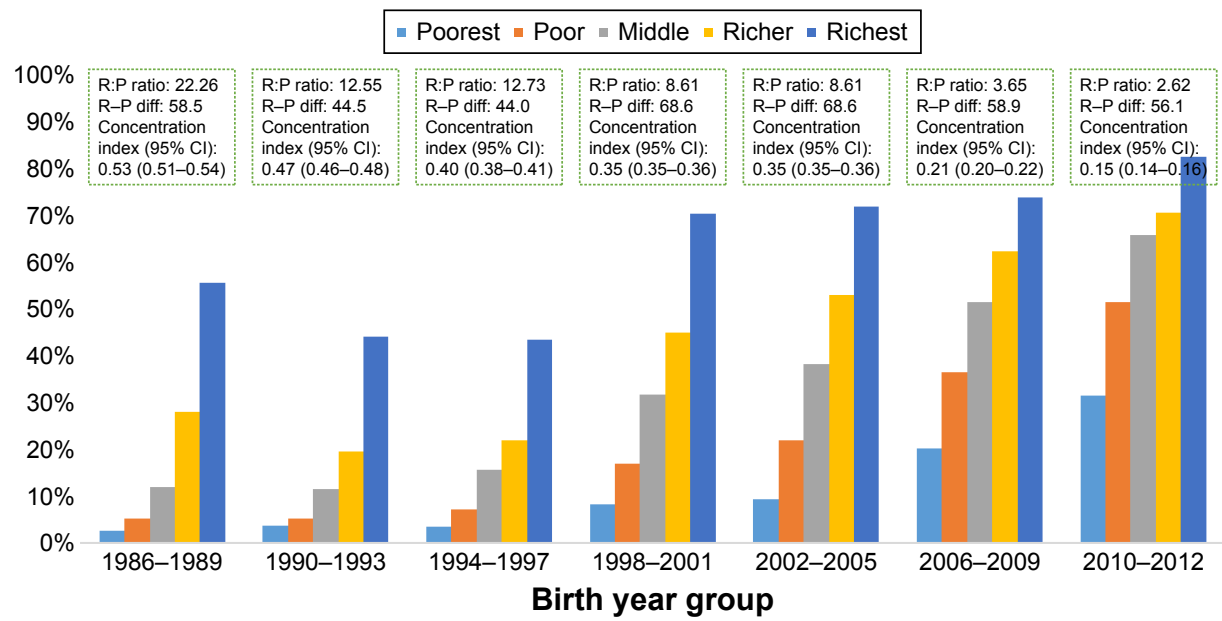

Figure 5 Trend in use inequity for institutional birth. 


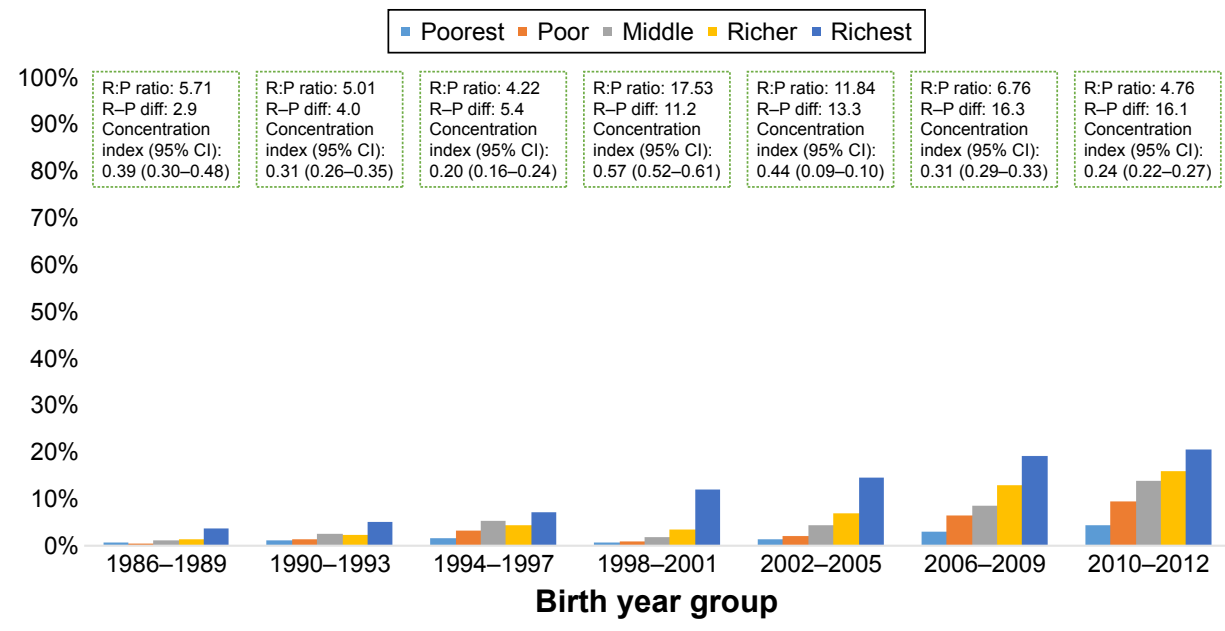

Figure 6 Inequity in use of cesarean section over time.

earlier. ${ }^{33,38,39}$ Undeniably, health facilities, health workers, and other resources are more concentrated in urban areas and in Java-Bali, ${ }^{11,28}$ making the services more readily available in these locations. From the annual trend, it was obvious that worse-off regions such as Maluku and Papua consistently lagged behind. These provinces continue to experience health worker shortage, limited infrastructure, and high poverty rates. ${ }^{39-41}$ Government decentralization in 2001 has been criticized for persistent geographic inequity. Multiple challenges continued to hinder health sector improvement through decentralization, including complicated funding and disbursement, limited capacity, and lack of transparency and accountability of local government. ${ }^{11,37,39}$

The government has implemented a number of health agendas. Community health centers in every subdistrict (Puskesmas) and village (Pustu) have been the cornerstone of Indonesian health system since the late 1960s. ${ }^{37}$ Maternal health care service was integrated through monthly community health post (Posyandu) with the involvement of community volunteer to increase ANC coverage and raise awareness for skilled attendance. ${ }^{28}$ To improve access to skilled attendance, birthing centers (Polindes) were established in every village. ${ }^{28}$ The availability of health workers was ensured through compulsory government services introduced in 1974, in which doctor, midwives, and nurse were deployed to different parts of Indonesia. ${ }^{42}$ Bidan di Desa (village midwife) was introduced in 1989, where existing nurses were given additional training on midwifery and deployed at a community level to conduct deliveries either in Polindes or at home. ${ }^{28}$ Unfortunately, due to difficult and isolated geographic location, smaller incentive package, and lack of opportunity for professional development, these jobs were not attractive to this new cadre of service providers leading to unfilled position and/or absenteeism. ${ }^{28,43}$ This situation may also explain the slow decrease in MMR despite the reduction in the proportion of home delivery. Furthermore, a study by the World Bank suggested a weak correlation between the availability of midwives and maternal and neonatal health outcomes in Indonesia, ${ }^{41}$ highlighting low quality of health care at the primary health care level. The condition is further impaired by a shortage of health facilities with proper equipment and supporting infrastructures, particularly in the Eastern part of Indonesia. ${ }^{44}$ This increasing shortage of human resources, supplies, logistic, and medicine also aggravated the discrepancy between geographic locations. ${ }^{43}$ Nevertheless, a full coverage of Puskesmas was achieved 20 years after its introduction ${ }^{37}$ with a relatively better distribution of health workers achieved in the latter part of the 1980s. ${ }^{43}$ The low service fee allowed the demand for health services to increase and the overall health outcomes to improve until 1997 when the Asian financial crisis started. ${ }^{37}$

During the crisis, an increase in prices for health care affected government expenditure and reduced quality in public sector while increasing service fee. ${ }^{45}$ At the same time, the households faced unemployment and decline in real wages and coped by cutting expenses including for health care. ${ }^{45}$ Consequently, there was a remarkable decrease in public health services ${ }^{37,45}$ and widened use inequity across region. ${ }^{37}$ To ensure access to health care for poor households, government started distributing health cards (Jaring Pengaman Sosial Bidang Kesehatan). ${ }^{37}$ However, the health cards were not considered effective because of ignorance of the beneficiaries and corruption among service providers. ${ }^{37}$

Deterioration of quality in public sector has also prompted preference to seek care in private sector, which is considered to have better perceived quality with only a slight difference in 
cost. ${ }^{37}$ Our findings support previous results, showing a bigger increase in private sector utilization during and after the crisis. In Indonesia, private sector consists largely of individual providers, especially midwives. Since decentralization, national government was no longer absorbing health workers into the government system, rather prompting doctor and midwives to find employment in private sector or open private practices. ${ }^{43}$ In addition, proliferation of private training institutions produced more graduates who could not find employment with government. ${ }^{43}$ It promoted these graduates to work as individual private providers, making them an important source of health care in Indonesia including maternal health. ${ }^{46}$ Unfortunately, government has minimal control of private sector with underdeveloped regulation and accreditation. ${ }^{42}$ This could have further negatively affected the quality of care. ${ }^{47,48}$

To respond to the MMR stagnation, Indonesian government has introduced a number of initiatives on maternal and neonatal health. One notable program is the Flying Health Care introduced to serve remote and challenging areas in eight provinces in Sumatera, Kalimantan, Papua, and Maluku. ${ }^{49}$ The program places a team of medical professionals for at least 3 months and rotates the team throughout the year. To increase the availability of medical professionals in remote areas, the government also started a mandatory placement for specialist doctors, including new graduates from obstetrics and pediatrics program. ${ }^{50,51}$ However, these program would need the support of good health infrastructure within the remote areas and indeed underline the issue of quality of care. ${ }^{51}$

To improve the referral system and quality of care, several innovative programs were introduced in the Eastern parts of Indonesia. East Nusa Tenggara province, for example, implemented a monitoring and referral system using short messaging service (SMS) for every pregnant woman since 2011 , called the $2 \mathrm{H} 2$ program. ${ }^{52}$ The $2 \mathrm{H} 2$ program aimed to detect pregnant women who have high risk of complicated childbirth and prepare them for referral by monitoring their status 2 days before and after childbirth. In this program, the local health workers responsible for monitoring send information via SMS to the $2 \mathrm{H} 2$ program center at the primary health centers, who subsequently relay the records to designated referral BEmOC Puskesmas or CEmOC hospital. ${ }^{52}$ At the hospital level, East Nusa Tenggara province also implemented the Sister Hospital approach, aimed to improve the quality of health workers in guiding childbirth and dealing with obstetric emergencies. Under the approach, local district hospitals in East Nusa Tenggara province are coupled with well-established hospitals in Java. These well-established hospitals are contracted to send specialist doctors or final-year residents to provide basic and emergency maternal health care services and on-the-job training for health workers at the partner hospitals and health centers. The Sister Hospital approach managed to increase the availability of 24-hour obstetric care at the participating district hospitals. ${ }^{53}$

The present study provides a multiyear trend in maternal health service utilization, which can be used as a benchmark for evaluation of recently launched Indonesia's national health insurance program, the JKN. The program started in January 2014 with the ambitious goal to cover all Indonesian population by 2019 . It consolidates all existing financial protection schemes into a single provider. The combined schemes include the pro-poor social insurance scheme (Askeskin or later known as Jamkesmas), scheme for government employee (Askes) and military personnel (ASABRI), mandatory private sector insurance (Jamsostek), local government-run insurance programs (Jamkesda), as well as specialized scheme for maternal health called Jampersal. In JKN, government fully subsidies the monthly premium for poor and near-poor, while the rest of the population is required to pay monthly premium on a mandatory basis. JKN provides a comprehensive continuum of care for maternal and newborn services, consisting of family-planning counselling and services, a minimum of four ANC visits, services for normal and complicated pregnancy and childbirth, as well as postpartum care. ${ }^{54}$

The previous insurance schemes had varying experiences. Askeskin increased service utilization by the poor; however, it also increased out-of-pocket spending. ${ }^{55}$ Jampersal had a limited effect in increasing maternal health service utilization because of widespread perception of the benefit and quality, ${ }^{18}$ as well as the nonexistence of funding for referral transportation to address accessibility issue. ${ }^{18,56,57}$ The current Jampersal scheme within the newly established JKN program covers ambulance service to close the gap in geographical access ${ }^{58}$ and geographical inequity. Experiences from other countries such as India, Cambodia, and Ghana showed that transportation is an important determinant and including transportation cost in financial protection scheme significantly improves access to maternal health care services. ${ }^{59-62}$ In addition, JKN provides opportunity for monitoring and improving the quality of care, especially in private sector facilities. ${ }^{63}$ However, there are criticisms that JKN is concentrating more on hospital-level clinical services than on community-level preventive and promotive services.

Finally, one interesting finding from the study is that demand-side financing program in Indonesia did not result in overutilization of c-section services, as observed in other settings. ${ }^{64} \mathrm{C}$-section rate in Indonesia of $16 \%$ falls just slightly above WHO conservative recommendation of $10 \%-15 \% .{ }^{65}$ This might also be another indication of persistent low utilization of health care in Indonesia in general. ${ }^{46,66}$ 


\section{Strength and limitations}

The current study is the first to explore the trend in maternal utilization and equity over time in Indonesia. The use of concentration index is a better way to measure inequity and hopefully can reflect the real situation in the country. However, this study also has some limitations. First, the recall period in the six IDHS surveys varied between 3 and 5 years. This long recall period might introduce bias and affect the accuracy of the information provided by the respondents. Second, as the latest data used were from 2012 IDHS, the more recent changes in access or equity could not be captured in this study.

\section{Conclusion and recommendation}

The current study indicates potential health gains with improved social determinants of health in Indonesia, which at the same time also reduces health inequities. However, access inequity still persists across asset quintile groups and across regions. Indonesian government needs to continue closing this gap and finding innovative ways to monitor progress, in which DHS data can be an aid. Comprehensive health insurance program introduced in 2014 has the potential to do this, by improving coverage and quality of health care services and lowering the financial barrier to access the care. With the increasing role of private sector, especially solo providers, it is important to consider ways to include them in the scheme, as well as to monitor and improve the quality of care they deliver.

\section{Acknowledgments}

No separate budgetary allocation was deployed for this study. All the authors dedicated their additional working hours to develop this manuscript. The authors also kindly acknowledge the European Union funded SHARE project at icddr,b to provide the publication charge. The funders had no role in study design, data collection and analysis, decision to publish, or preparation of the manuscript.

\section{Author contributions}

All authors made substantial contributions to conception and design, acquisition of data, or analysis and interpretation of data; took part in drafting the article or revising it critically for important intellectual content; gave final approval of the version to be published; and agree to be accountable for all aspects of the work.

\section{Disclosure}

The authors report no conflicts of interest in this work.

\section{References}

1. Starrs A. Safe motherhood initiative: 20 years and counting. Lancet. 2006;368(9542):1130-1132.

2. Starrs A. The Safe Motherhood Action Agenda: Priorities for the Next Decade. Washington, DC: The World Bank; 1998.

3. Kunst AE, Houweling T. A global picture of poor-rich differences in the utilisation of delivery care. Stud Health Serv Organ Policy. 2001;17: 293-311.

4. Murray SF, Hunter BM, Bisht R, Ensor T, Bick D. Demand-side financing measures to increase maternal health service utilisation and improve health outcomes: a systematic review of evidence from lowand middle-income countries. JBI Database Syst Rev Implement Rep. 2012;10(58):4165-4567.

5. Gwatkin DR. Reducing Health Inequalities in Developing Countries. Washington, DC: World Bank; 2002.

6. Kawachi I, Subramanian S, Almeida-Filho N. A glossary for health inequalities. J Epidemiol Community Health. 2002;56(9):647-652.

7. Report of the Open Working Group of the General Assembly on Sustainable Development Goals. Sixty-eighth session of the United Nations General Assembly: United Nations; 2014. http://undocs.org/A/68/970. Accessed January 29, 2017.

8. Sustainable Development Solutions Network. Indicators and a monitoring framework for the sustainable development goals. Launching a data revolution for the SDGs. 2015. Sustainable Development Solutions Network. Available from: http://unsdsn.org/wp-content/uploads/2015/05/FINALSDSN-Indicator-Report-WEB.pdf. Accessed December 5, 2017.

9. Suryadarma D, Widyanti W, Suryahadi A, Sumarto S. From Access to Income: Regional and Ethnic Inequality in Indonesia. Jakarta: SMERU Research Institute; 2006.

10. Mahendradhata Y, Trisnantoro L, Listyadewi S, et al. The Republic of Indonesia Health System Review. In: Hort K, Patcharanarumol W, editors. Health Systems in Transition. India: World Health Organization; 2017.

11. Hodge A, Firth S, Marthias T, Jimenez-Soto E. Location matters: trends in inequalities in child mortality in Indonesia. Evidence from repeated cross-sectional surveys. PLoS One. 2014;9(7):e103597.

12. World Bank, UKAid. Accelerating improvement in maternal health: why reform is needed. Indonesia Health Sector Review. Washington, DC. World Bank, UKAid; 2010

13. World Bank Group. Life expectancy at birth, total (years). Available from: https://data.worldbank.org/indicator/SP.DYN.LE00. IN?view=chart. Accessed June 14, 2017.

14. Bureau of Statistics Indonesia, National Population and Family Planning Board (BKKBN), Ministry of Health Indonesia, ICF International. Indonesia Demographic and Health Survey 2012. Jakarta: Bureau of Statistics Indonesia, National Population and Family Planning Board (BKKBN), Ministry of Health Indonesia and ICF International; 2013.

15. Arcaya MC, Arcaya AL, Subramanian S. Inequalities in health: definitions, concepts, and theories. Revista Panamericana de Salud Pública. 2015;38(1):261-271

16. Braveman P. What are health disparities and health equity? We need to be clear. Public Health Rep (Washington, DC: 1974). 2014; 129(Suppl 2):5-8.

17. Frankenberg E, Thomas D. Women's health and pregnancy outcomes: do services make a difference? Demography. 2001;38(2):253-265.

18. Achadi EL, Achadi A, Pambudi E, Marzoeki P. A study on the implementation of jampersal policy in Indonesia. Health, Nutrition, and Population (HNP) discussion paper. Washington, DC: World Bank Group. 2014. Available from: https://openknowledge.worldbank.org/ handle/10986/20740 License

19. Chomitz KM. What Do Doctors Want?: Developing Incentives for Doctors to Serve in Indonesia's Rural and Remote Areas. Washington, DC: World Bank Publications; 1998.

20. Meliala A, Hort K, Trisnantoro L. Addressing the unequal geographic distribution of specialist doctors in Indonesia: the role of the private sector and effectiveness of current regulations. Soc Sci Med. 2013;82: $30-34$. 
21. Hidayat B, Mundiharno, Nemec J, Rabovskaja V, Rozanna CS, Spatz J. Financial Sustainability of the National Health Insurance in Indonesia: A First Year Review. Jakarta: Indonesian-German Social Protection Programme (SPP); 2015.

22. Hatt L, Stanton C, Makowiecka K, Adisasmita A, Achadi E, Ronsmans C. Did the strategy of skilled attendance at birth reach the poor in Indonesia? Bull World Health Organiz. 2007;85(10):774-782.

23. Rahman A, Nisha MK, Begum T, Ahmed S, Alam N, Anwar I. Trends, determinants and inequities of 4+ ANC utilisation in Bangladesh. J Health Popul Nutr. 2017;36(1):2.

24. Filmer D, Pritchett LH. Estimating wealth effects without expenditure data - or tears: an application to educational enrollments in states of India. Demography. 2001;38(1):115-132.

25. Kakwani NC. On the measurement of tax progressivity and redistributive effect of taxes with applications to horizontal and vertical equity. Adv Econometrics. 1984;3:149-168.

26. StataCorp L. Stata data analysis and statistical Software. Spec Ed Rel. 2007:10:733

27. Callister LC, Edwards JE. Sustainable development goals and the ongoing process of reducing maternal mortality. J Obstetric Gynecologic Neonatal Nurs. 2017;46(3):e56-e64.

28. Joint Committee on Reducing Maternal and Neonatal Mortality in Indonesia; Development S, and Cooperation; Policy and Global Affairs; National Research Council; Indonesian Academy of Sciences. The Indonesian Healthcare System. Reducing Maternal and Neonatal Mortality in Indonesia: Saving Lives, Saving the Future. Washington, DC: National Academies Press; 2013.

29. Erlyana E, Damrongplasit KK, Melnick G. Expanding health insurance to increase health care utilization: will it have different effects in rural vs urban areas? Health Policy. 2011;100(2):273-281.

30. Asian Development Bank. Asian Development Outlook 2016: Asia's Potential Growth. Manila: Asian Development Bank; 2016.

31. Ahmed S, Creanga AA, Gillespie DG, Tsui AO. Economic status, education and empowerment: implications for maternal health service utilization in developing countries. PLoS One. 2010;5(6): e11190.

32. Kruk ME, Prescott MR, Galea S. Equity of skilled birth attendant utilization in developing countries: financing and policy determinants. Am J Public Health. 2008;98(1):142-147.

33. Titaley CR, Dibley MJ, Roberts CL. Factors associated with underutilization of antenatal care services in Indonesia: results of Indonesia Demographic and Health Survey 2002/2003 and 2007. BMC Public Health. 2010;10(1):485.

34. United Nations. The Millennium Development Goals Report 2015. New York: United Nations; 2015.

35. McKinnon B, Harper S, Kaufman JS. Do socioeconomic inequalities in neonatal mortality reflect inequalities in coverage of maternal health services? Evidence from 48 low and middle-income countries. Maternal Child Health J. 2016;20(2):434-446.

36. Mulholland E, Smith L, Carneiro I, Becher H, Lehmann D. Equity and child-survival strategies. Bull World Health Organiz. 2008; 86(5):399-407.

37. Kristiansen S, Santoso P. Surviving decentralisation? Impacts of regional autonomy on health service provision in Indonesia. Health Policy. 2006;77(3):247-259.

38. Jimenez Soto E, La Vincente S, Clark A, et al. Investment case for improving maternal and child health: results from four countries. $B M C$ Public Health. 2013;13(1):601.

39. Heywood P, Choi Y. Health system performance at the district level in Indonesia after decentralization. BMC Int Health Hum Rights. 2010;10(1):3.

40. Central Bureau of Statistics Indonesia, National Population and Family Planning Board (BKKBN), Ministry of Health Indonesia, ICF International. Indonesia Demographic And Health Survey 2012. Jakarta: Central Bureau of Statistics Indonesia, National Population and Family Planning Board (BKKBN), Ministry of Health Indonesia, and ICF International; 2013.
41. Anderson I, Meliala A, Marzoeki P, Pambudi E. The Production, Distribution, and Performance of Physicians, Nurses, and Midwives in Indonesia: an Update. Washington, DC: World Bank; 2014:1-56.

42. Heywood P, Harahap NP. Health facilities at the district level in Indonesia. Aust N Z Health Policy. 2009;6(1):13.

43. Heywood PF, Harahap NP. Human resources for health at the district level in Indonesia: the smoke and mirrors of decentralization. Hum Resour Health. 2009;7(1):6.

44. National Institute of Health Research and Development (NIHRD), Ministry of Health Indonesia. Indonesia Basic Health Research 2010. Jakarta: Indonesia. Ministry of Health; 2013.

45. Waters H, Saadah F, Pradhan M. The impact of the 1997-98 East Asian economic crisis on health and health care in Indonesia. Health Policy Plann. 2003;18(2):172-181.

46. Hidayat B, Thabrany H, Dong H, Sauerborn R. The effects of mandatory health insurance on equity in access to outpatient care in Indonesia. Health Policy Plann. 2004;19(5):322-335.

47. Barber SL, Gertler PJ, Harimurti P. Differences in access to high-quality outpatient care in Indonesia. Health Affairs (Project Hope). 2007; 26(3):w352-w366.

48. Supratikto G, Wirth ME, Achadi E, Cohen S, Ronsmans C. A districtbased audit of the causes and circumstances of maternal deaths in South Kalimantan, Indonesia. Bull World Health Organiz. 2002;80(3): 228-235.

49. Kementerian Kesehatan Republik Indonesia: Menuju Masyarakat Sehat yang Mandiri dan Berkeadilan. Kinerja Dua Tahun Kementerian Kesehatan Republik Indonesia 2009-2011. Jakarta: Kementerian Kesehatan Republik Indonesia; 2011.

50. Minister of Health. Minister of Health regulation No. 69 of 2016 on the implementation of mandatory service for specialist doctors to achieve universal coverage for specialist care in Indonesia. Jakarta: Ministry of Health of the Republic of Indonesia. Available from: http://ditjenpp. kemenkumham.go.id/arsip/bn/2017/bn226-2017.pdf. Accessed September 9, 2017.

51. Pertiwi IM. Perencanaan Program Pemenuhan Dokter Spesialis Dasar di RSD Balung Kabupaten Jember Tahun 2016. Digital Repository Universitas Jember. Jember: Universitas Jember; 2017.

52. Pardosi JF, Parr N, Muhidin S. Local government and community leaders' perspective on child health and mortality and inequity issues in rural Eastern Indonesia. J Biosoc Sci. 2017;49(1):123-146.

53. Center for Health Policy and Management, Faculty of Medicine, Universitas Gadjah Mada. Evaluation workshop for sister hospital and performance and management leadership program in East Nusa Tenggara; 2014. Available from: http://mutukia-ntt.net/index.php/ laporan/sister-hospital. Accessed September 9, 2017.

54. Minister of Health. Minister of Health regulation No. 52 of 2016 on standard tariffs for health services in the national health insurance implementation. Jakarta: Ministry of Health of the Republic of Indonesia. Available from: http://djsn.go.id/storage/app/uploads/ public/58d/487/cdd/58d487cdd4630003169427.pdf. Accessed September 9, 2017.

55. Sparrow R, Suryahadi A, Widyanti W. Social health insurance for the poor: Targeting and impact of Indonesia's Askeskin programme. Soc Sci Med. 2013;96:264-271.

56. Erpan LN, Laksono Trisnantoro T. Koordinasi pelaksanaan pembiayaan program kesehatan ibu dan anak di Kabupatek Lombok Tengah Provinsi Nusa Tenggara Barat tahun 2011. Jurnal Kebijakan Kesehatan Indonesia. 2012;1(1):42-51.

57. Noerdin E. Transport, health services and budget allocation to address maternal mortality in rural Indonesia. Transp Commun Bull Asia Pac. 2014;84:1-14.

58. Minister of Health. Minister of health regulation no. 71 of 2016 on the technical guideline for the use of non-infrastructural special health budget for the budget year 2017. Jakarta: Ministry of Health of the Republic of Indonesia. Available from: http://hukor.kemkes.go.id/uploads/produk_ hukum/PMK_No._71_ttg_JUKNIS_Penggunaan_DAK_NONFISIK_ Bidang_Kesehatan_TA_2017_.pdf. Accessed September 9, 2017. 
59. Arsenault C, Fournier P, Philibert A, et al. Emergency obstetric care in Mali: catastrophic spending and its impoverishing effects on households. Bull World Health Organiz. 2013;91(3):207-216.

60. Atuoye KN, Dixon J, Rishworth A, Galaa SZ, Boamah SA, Luginaah I. Can she make it? Transportation barriers to accessing maternal and child health care services in rural Ghana. BMC Health Serv Res. 2015; 15(1):333.

61. Mohanty SK, Srivastava A. Out-of-pocket expenditure on institutional delivery in India. Health Policy Plann. 2012;28(3):247-262.

62. Ir P, Horeman D, Narin S, Van Damme W. Improving access to safe delivery for poor pregnant women: a case study of vouchers plus health equity funds in three health districts in Cambodia. In: Richard F, Witter S, De Brouwere V, editors. Reducing financial barriers to obstetric care in low-income countries: studies in health services organisation \& policy no. 24. Antwerp: ITG Press; 2008:225-255.
63. Bennett S, Bloom G, Knezovich J, Peters DH. The future of health markets. Globalization Health. 2014;10(1):51.

64. Anwar I, Nababan HY, Mostari S, Rahman A, Khan JA. Trends and inequities in use of maternal health care services in Bangladesh, 1991-2011. PLoS One. 2015;10(3):e0120309.

65. Betran A, Torloni M, Zhang J, Gülmezoglu A. WHO Statement on caesarean section rates. BJOG. 2016;123(5):667-670.

66. Harimurti P, Pambudi E, Pigazzini A, Tandon A. The nuts \& bolts of Jamkesmas Indonesia's government-financed health coverage program for the poor and near-poor. UNICO Studies Series No. 8. Washington DC; World Bank, 2013.

\section{Publish your work in this journal}

The International Journal of Women's Health is an international, peerreviewed open-access journal publishing original research, reports, editorials, reviews and commentaries on all aspects of women's healthcare including gynecology, obstetrics, and breast cancer. The manuscript management system is completely online and includes a very quick and fair peer-review system, which is all easy to use. Visit http://www.dovepress.com/testimonials.php to read real quotes from published authors.

Submit your manuscript here: http://www.dovepress.com/international-journal-of-womens-health-journal 